\title{
A Study on the Behavioral Change of Passengers on Sustainable Air Transport after COVID-19
}

\author{
Ki-Han Song $(\mathbb{D})$ and Solsaem Choi * \\ Department of Aviation, Korea Transport Institute, Sejong-si 30147, Korea; kihansong@koti.re.kr \\ * Correspondence: thftoa9@koti.re.kr
}

Received: 29 September 2020; Accepted: 28 October 2020; Published: 5 November 2020

check for updates

\begin{abstract}
From the perspective of the sustainability of aviation demand, we investigated passenger perceptions with regards to whether or not Korean people will resume the use of air transport after COVID-19. Based on five factors-the prevalence of COVID-19, requirements for self-isolation, circumstances at the destination, social atmosphere with regards to overseas travel, and level of preventative measures employed in the aviation service sector-a structured questionnaire was developed using confirmatory factor analysis. Based on these, the main levels of determination per factor were derived and a structured path for the recovery of aviation demand via structural equation analysis between factors was analyzed. The five factors established above were found to have a significant impact on passenger perceptions with regards to the restart of using air transport. It was found that people may consider resuming overseas travel with air transport, prior to the development of a COVID-19 cure or vaccine, corresponding to relaxed requirements for self-isolation if there is a fall in the number of confirmed cases. In addition, it was determined that the unconditional lifting of self-isolation requirements without considerations for the hygienic conditions of the destination has limitations in how much it will lead to the resumption of air travel. We hope that this study will serve as a starting point for other studies monitoring passenger behavior in the future and that it will lead to the development of sustainable strategies for recovering aviation demand.
\end{abstract}

Keywords: passenger behavior; air transport sustainability; structural equation modeling

\section{Introduction}

From the perspective of the sustainability of aviation demand, we seek to understand behaviors with regards to post-COVID-19 air transportation utilization following changes in the perceptions of individual passengers. COVID-19 caused enormous damage in aviation that a 59-62\% decrease by year in terms of global air transport passengers might be expected according to International Civil Aviation Organization (ICAO) [1] and it is even worse since nobody knows when the pandemic will end. It is an unprecedented pandemic even compared to recent similar cases, such as the $35 \%$ global passenger decrease in the relevant year because of SARS and $12 \%$ Korean revenue passenger $\mathrm{km}$ decrease in a relevant month due to MERS [2]. We guess that damage and uncertainty from COVID-19 may have already permanently influenced passenger's behavior changes, and it would be needed to be carefully investigated that behavior transition after COVID-19 to enhance sustainability in the aviation industry.

There are surveys being conducted on behaviors with regards to air transportation in the post-COVID-19 era [3,4], but they are limited to surveys with simple responses about conditions related to patterns of air traffic use. For example, although the development of a vaccine related to COVID-19 and changes in the degree of lockdown between countries are expected to affect the resumption of air travel, there have been limitations in analysis concerning their mutual impact. Through a structured survey administered to South Korean people, this study confirmed factors that are expected to affect behavioral changes in the post-COVID-19 era with regards to air transportation 
utilization related to infectious diseases and has identified the mutual structure of factors and their relation to air transportation use.

This study goes beyond the work of other ongoing studies about airline selection and the loyalty of air travelers [5] and also studies about the selection of airports [6], and focuses the perceptions and choosing behaviors of air travelers with regards to the resumption of postpandemic air travel. COVID-19 has had a greater impact on the aviation industry than previous infectious diseases such as SARS and MERS, and South Korea is experiencing an unprecedented 98\% drop in international flight demand (as of June 2020). The COVID-19 pandemic is predicted to greatly affect society and the economy globally [7]. Some arguments predict a completely different world after COVID-19, calling it the "Post-COVID-19 Era" or the "New Normal" [8]. Such changes will result in different passenger perceptions and behaviors with regards to their air transportation use.

However, previous studies have limited the factors they analyze to the choices of air travelers and aviation systems such as airlines and airports, and to this point no academic research has been conducted which studies the changing use behaviors in relation to infectious diseases. For example, there have been past studies on choices such as the one conducted by [9], which presented factors such as prices and flight scheduling that affect airline selection but there have been no studies on factors affecting air travel behavior since the epidemic. Since COVID-19 is an unprecedented pandemic, factors that were not considered in previous studies, such as fear of infectious diseases, entry prohibition, and self-isolation requirements, are likely to affect future air travel behavior. This study seeks to survey perceptions of air travel related to infectious diseases.

As there are limitations when comparing changes in air travel behavior resulting from COVID-19 to past cases of epidemics, this study chose to directly survey behaviors with regards to air travel. To this end, a survey was organized and confirmatory factor analysis was conducted on candidate factors that would influence the resumption of air travel. Based on the analysis of structural routes, the behavior of air travelers was then reviewed depending on perceptions towards the resumption of air travel. In addition to the structural equation analysis, there have been prior studies on airline selection [10-13] and airport selection [14-17] using logit models, etc., but since this study is dealing with an unprecedented infectious disease, there may arise significant discrepancies in the setting of reference points for a stated preference (SP) survey. Therefore, this study applied structural equation analysis focused on post-COVID-19 perceptions and behaviors of air travelers with regards to the resumption of air travel.

This study examines the applicability of the methodology proposed in this study and examples of its application in the aviation sector among models based on the perceptions of individual passengers in Section 2. Section 3 presents the methodology of this study while Section 4 presents the analysis results. Section 5 discusses behavioral changes in post-COVID-19 air travelers.

\section{Literature Review}

Studies on user behavior in connection with air transportation have been conducted with regularity. In terms of methodologies, a logit analysis [18-20] and structural equation analysis [21-23] have been primarily adopted. There are also other methodologies applied, although they are less common, such as the analysis of air traveler satisfaction using text-mining [24], and comparative analysis of travelers' behavioral patterns through cross-cultural studies [25].

Logit analysis, a statistical technique used to analyze the relationship between a dependent variable and an independent variable, has been widely used when dealing with topics related to airport and airline choices [26]. Suzuki [16] developed and evaluated a nested logit model of airport-airline choice that incorporates a two-step decision process for air travelers, while Ishii et al. [6] evaluated a weighted-conditional logit model to study the supply characteristics of airlines and airports. Recently, Lee et al. [27] used the SP technique and combined it with a logit model to analyze travelers' choice with regards to mode of transport and used this to suggest improvements in regard to the goodness of the fit of the models. 
Studies that reflect the factors and drivers of choices based on logit models have also been regularly conducted. For example, Dolnicar et al. [5] presented fares, frequency of in-flight services, and frequent flyer memberships as key factors in airline choice, and Ong and Tan [12] presented behavioral factors such as fares, routes, and reservation methods as predictor variables in making choices between Malaysia Airlines and Asian LCCs through logit analysis. To date, however, no academic research has been conducted on the factors that influence air travelers' behavior since the outbreak of this unprecedented epidemic.

Structural equation analysis is based on sociology and psychology as a methodology with the combined characteristics of confirmatory factor analysis and multiple regression analysis/path analysis $[28,29]$. The structural equation has advantages, such as control over measurement errors, accuracy of covariance coefficients and regression coefficients, ease of using parameters, and availability of statistical evaluation of theoretical models [14]. Structural equation models have been applied to various problems in the field of aviation, such as the loyalty of airline passengers [10,30], low-cost strategies of airlines [31,32], job satisfaction of airline employees [33], and the financial performance of airlines [34].

In particular, many examples of structural equation applications for the aviation sector can be found in studies related to aviation services. Bogicevic et al. [35] suggested that airport design characteristics and pleasant scents can improve passenger satisfaction based on a structural equation that sets design, scent, functional organization, air/lighting conditions, seating, and cleanliness as airport servicescape factors. Chen and Chao [9] explored airline choice factors, comparing the choices of passengers with different demographics and analyzing the factors emphasized by passengers from Taiwan and China when selecting airlines. Then they identified the five factors of ground services, convenience, in-flight services, price, and travel availability and presented their applicability for market segmentation and marketing strategies. Han [36] presented the development of an integrative model to investigate relationships between ambient conditions, space (in the flight cabin), cognitive and affective evaluations, satisfaction, and behavioral intentions. As an example, related to safety perceptions, Wang [37] examined the architecture of the relationships between components of organizational safety culture within the Aviation Divisions of the Ministry of National Defense in Taiwan.

For a case similar to COVID-19, Lai and Lu [38] took an approach of using an intervention model to look into the impact of the September 11 terrorist attacks on air transport passenger demand in the US, and Lirn and Sheu [39] analyzed behavioral characteristics of transportation mode-choice after an airline accident based on the 11 September crisis. These studies were found to have limitations insofar as they apply to the current global pandemic of COVID-19 due to their localities based around domestic situations in the United States or their limited methodologies confined to the demand perspective and mode of transportation choices.

As a result of reviewing these prior studies, a structural equation was considered to be more appropriate than the logit model as a methodology for investigating behavioral changes in air passengers since the outbreak of COVID-19. As COVID-19 is an unprecedented crisis, there are a lack of studies on existing factors to apply the logit model and there are limitations to structuring SP surveys due to uncertainties with regards to future situations. In addition, the structural equation allows us to identify the structures by which several factors interact with each other in relation to the resumption of air travel based on the perceptions regarding COVID-19 of potential air travelers.

\section{Methodology}

The research question in this paper is to investigate factors which influence passengers' perception on resuming the use of air transport after COVID-19. We investigated hypotheses of the 5 factors that will influence passenger's perception (Figure 1). The factors considered for determining the recovery of post-COVID-19 air transportation used in this study were the COVID-19-related factor (C), self-isolation upon entry and departure factor $(\mathrm{Q})$, destination-related factor $(\mathrm{D})$, social atmosphere towards overseas travel (S), and the level of aircraft/airport management related to infectious diseases (A). 


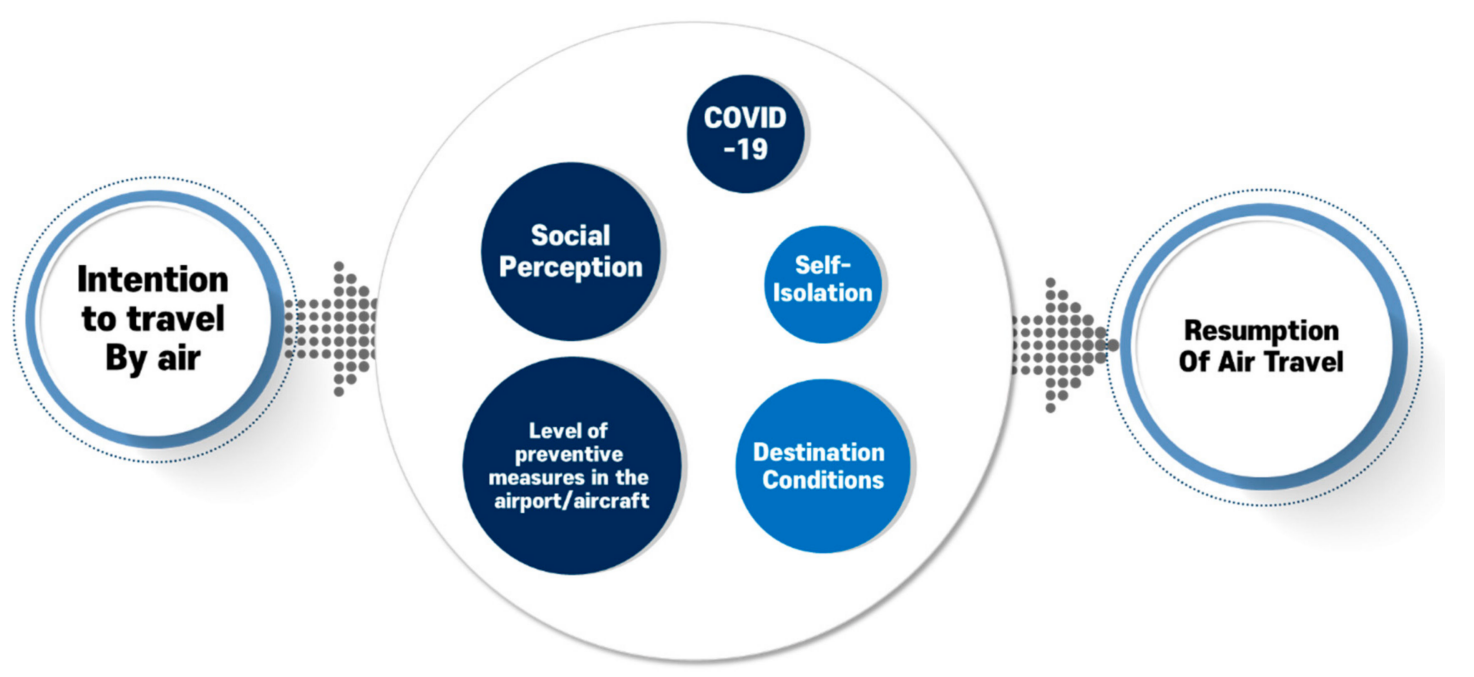

Figure 1. Conceptual diagram.

To date, there has been no research on factors for the recovery of air travel following the damage brought about by infectious diseases such as COVID-19. However, instead of exploratory factor analysis to find the structure, we applied a structural equation model to validate the proposed 5 factor hypotheses, in order to focus on our interesting factors and the structured model based on these from the implementation perspective. Thus, this study established factors through brainstorming, based on previous studies $[3-5,8,10,12,13,16,24,30,31,35]$, and was conducted by our research team with an advisory panel which consist of government officers, professors, research institute researchers, and pilot tests of 30 aviation experts. The experts who had worked at the research institutes (i.e., aviation, marketing, transportation planning), universities (i.e., aviation, business management), airlines (i.e., marketing), and airport corporations (i.e., strategy, marketing) for more than 10 years participated in the validity check of the initial questionnaires.

The questionnaire had questions for each factor and consisted of 45 total questions. At first, more than 10 questions were set for each factor, with a total of 32 questions finally established after gathering the opinions of 30 people on the questionnaire itself. As a result, 4 to 12 survey questions were created for each factor and a 5-point Likert scale was applied to assess whether or not respondents intended to resume air travel (see Appendix A for details on the questions).

In this study, an initial structural equation containing all the questions from the survey was constructed and it was evaluated as to whether the early model had an appropriate goodness of fit through confirmatory factor analysis. Then, we deleted questions based on the precondition criteria to improve goodness of fit and construct the final model. A structural equation model, also known as covariance structural modeling, searches the relation between factors, which consists of a measurement model, confirmatory factor analysis, and structural model via multiple regression analysis/path analysis as following Equation (1) $[28,29,40]$

$$
\begin{aligned}
& \mathrm{Z}_{1}=\mathrm{Y}_{11}+\mathrm{Y}_{12}+\mathrm{Y}_{13}+\cdots+\mathrm{Y}_{1 p} \\
& \mathrm{Z}_{2}=\mathrm{Y}_{21}+\mathrm{Y}_{22}+\mathrm{Y}_{23}+\cdots+\mathrm{Y}_{1 q} \\
& \mathrm{Z}_{p}=\mathrm{Y}_{p 1}+\mathrm{Y}_{p 2}+\mathrm{Y}_{p 3}+\cdots+\mathrm{Y}_{p q}
\end{aligned}
$$

where Z: quantitative variable, Y: quantitative or qualitative variable, $\mathrm{p} \mathrm{q}$ : number of variable.

It is known that a TLI (Tucker-Lewis index) over 0.90 [41-43] and CFI (comparative fit index) over 0.9 [41] means that the goodness of fit is reasonable. Root mean square of error approximation (RMSEA) supplementing the limitation of Chi statistics is recommended to be between 0.05 and 0.08 [44]. We applied CFI, TLI, and RMSEA as the goodness of fit index simultaneously with Chi statistics because Chi statistics are sensitive to the sample size and in the cases of over 400 sample 
size it mostly tends to be concluded that it is statistically reasonable [45]. Therefore, we attempted to determine whether the $p$ values of regression weights were meaningful and if the standardized regression weights were less than 0.5 or if the values of squared multiple correlations were less than 0.4 , such variables were eliminated.

In addition, if the variance turned out to be negative, the corresponding variables and errors were eliminated. It is known as a Heywood case when variances are a negative number in a structural equation model (Figure 2), and it means that the error of measurement is smaller than 0 . To solve this case, deleting the relevant item or setting variance as a very small number is implemented [46]. In this paper, we applied the first method to consider a Heywood case.

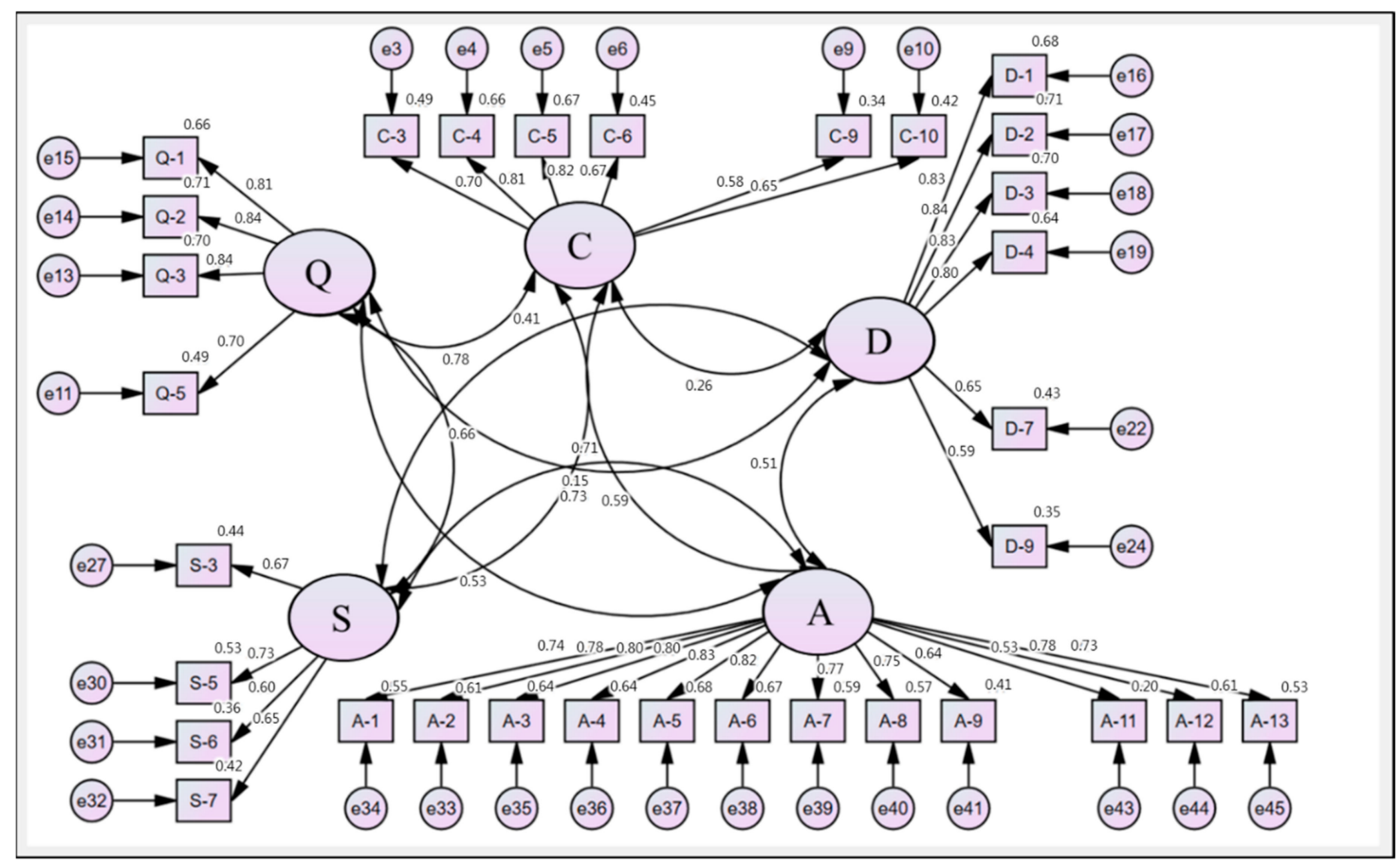

Figure 2. Structural equation model. Note: $\mathrm{C}=\mathrm{COVID}-19$ prevalence factor; $\mathrm{Q}=$ factor of self-isolation period upon entry and departure; $\mathrm{D}=$ factor of conditions at overseas travel destination; $\mathrm{S}=$ factor of social atmosphere related to overseas travel; $\mathrm{A}$ = factor of the level of aircraft/airport management.

\section{Analysis Results}

\subsection{Data and Statistics}

The survey was conducted online from July 17 to July 21, 2020 on 1200 Koreans aged 18 or older who had experience in overseas travel within the last year or who planned to depart the country within the next year. Proportional allocation method by gender (male/female) and age group (20-29, 30-39, $40-49,50-59,60-)$ was applied for sampling. The responses to individual questions consisted of a Likert scale of 1 to 5 points (Strongly Disagree-Strongly Agree). We surveyed 1.1 times more than the target sample size in this paper, and checked the normality based on skewness and kurtosis.

A simple aggregate of the responses indicates that, on average, the question which was answered most negatively for the COVID-19-related factor (C) was C-4. According to the findings on the C-4, C-5, and C-6 questions based on the number of new confirmed cases per day, the tendency to resume air travel for each question gradually increased as the number of new confirmed cases per day decreased from 100 to 50 to 10 . On average, the questions with the most positive responses for factor $C$ were $C-1$ and C-2, which were related to the development of a cure or vaccine, or a resolution of the pandemic as a factor of instability. These average results appear to be consistent with the range reasonably expected prior to the survey. 
As for the factor of self-isolation upon entry and departure $(\mathrm{Q})$, the question that on average showed the most positive responses was Q-3. Answers to this question revealed that if the self-isolation period fell to just one week, they would travel by air again. The question with the most negative response was Q-2, where the isolation period was 2 weeks. According to average responses, it is reasonable to interpret that the current two-week self-isolation in Korea has a significant impact on no longer wanting to travel abroad. According to the results of the survey section on the destination-related factors (D), the most positive responses were given to D-1, which was a question regarding the sanitary conditions of tourist destinations. It was found that the perceptions towards the overall sanitary conditions, not individual facilities, has a significant impact on the resumption of air travel.

According to the survey results on the section about social atmosphere factors regarding overseas travel (S), the question with the most positive responses was S- 4 on concerns over contracting infectious diseases during overseas travel. Responses indicated that social perceptions could significantly impact individual choices. The question that drew the most positive responses in the survey results on the level of aircraft/airport management related to infectious diseases (A) was A-6 on the periodic management of airport facilities. Responses indicated that the level of preventive measures at the airport were perceived as being important.

\subsection{SEM Result}

In the process of building a final model, the measurement variables of C-1, C-2, C-8, Q-4, D-5, D-6, D-8, D-10, S-2, S-4, A-10, which displayed standardized regression weights of less than 0.5 and the measurement variables of C-1, C-2, C-7, C-8, C-9, Q-4, D-5, D-6, D-8, D-10, S-1, S-4, A-10, which showed SMC of less than 0.4 were removed. The goodness of fit of the final measurement model was $\chi^{2}=2435.376(p<0.001)$, TLI: 0.907, CFI: 0.915, RMSEA: 0.060 (Table 1$)$, thus the model is believed to be suitable in that it satisfies CFI $<0.9$, TLI $<0.9$, RMSEA $>0.08$, which is the general fitness standard [40] of the general fitness indices (RMSEA, TLE, and CFI). The confirmatory factor analysis found that the paths reaching from latent variables of COVID-19-related factors (C), factor of self-isolation upon entry and departure $(\mathrm{Q})$, destination-related factor $(\mathrm{D})$, social atmosphere towards overseas travel (S), and level of aircraft/airport management related to infectious diseases (A) to the measurement variables were all significant $(p<0.01)$. In addition, a review of the correlation coefficients between factors and standard errors showed that the validity of the determination was certain.

Table 1. Model's goodness of fit index.

\begin{tabular}{cccccc}
\hline \multicolumn{6}{c}{ Model's Goodness of Fit Index } \\
\hline \multirow{2}{*}{ All } & $x^{2}(\mathrm{CMIN})$ & RMSEA & TLI & CFI & CMIN/DF \\
\cline { 2 - 6 } & 2435.376 & 0.06 & 0.907 & 0.915 & 5.364 \\
\hline
\end{tabular}

If we look into the measurement variables (standardized coefficients) derived from the confirmatory factor analysis results in detail, question C-5 (I would travel abroad if the number of new confirmed COVID-19 cases per day falls below 50) was found to be relatively important in the COVID-19-related factors. The importance of Q-3 (I would travel abroad if the self-isolation period upon entry and departure becomes reduced to one week or less) was relatively high in the factor of self-isolation upon entry and departure (Q), while, in the destination-related factor (D), the question D-2 (I would travel abroad if the sanitary condition of the accommodation facilities in the country of my destination were good) was relatively high in importance. In the social atmosphere related to overseas travel (S) and the level of aircraft/airport management related to infectious diseases (A), the importance was relatively high for the question S-5 (I would travel abroad if the government does not restrict overseas travel) and question A-5 (I would travel abroad by air if all airport employees and cabin crew wear a face mask). As a result, the confirmatory factor analysis (Table 2) showed that the value of the 
overall measurement variables (standardized coefficients) were 0.534 and -0.843 , and all variables were derived to be meaningful at a value of 0.35 or above.

Table 2. Results of confirmatory factor analysis.

\begin{tabular}{|c|c|c|c|c|c|}
\hline \multirow{2}{*}{ Latent Variable } & \multirow{2}{*}{ Measurement Variable } & \multicolumn{2}{|c|}{ Estimate } & \multirow{2}{*}{ S.E. } & \multirow{2}{*}{ C.R. } \\
\hline & & B & $\beta$ & & \\
\hline \multirow{6}{*}{ COVID-19-related factor (C) } & $\mathrm{C}-3$ & 1 & 0.701 & & \\
\hline & $\mathrm{C}-4$ & 1.122 & 0.813 & 0.044 & $25.796^{* * *}$ \\
\hline & $C-5$ & 1.1 & 0.821 & 0.042 & $26.009 * * *$ \\
\hline & C-6 & 0.974 & 0.671 & 0.045 & $21.576^{* * *}$ \\
\hline & C-9 & 0.868 & 0.582 & 0.046 & $18.802^{* * *}$ \\
\hline & C-10 & 0.952 & 0.646 & 0.046 & $20.793^{* * *}$ \\
\hline \multirow{4}{*}{$\begin{array}{l}\text { Factor of self-isolation upon } \\
\text { entry and departure }(\mathrm{Q})\end{array}$} & Q-5 & 1 & 0.698 & & \\
\hline & Q-3 & 1.12 & 0.835 & 0.043 & $26.351 * * *$ \\
\hline & Q-2 & 1.088 & 0.843 & 0.041 & $26.569^{* * *}$ \\
\hline & Q-1 & 1.117 & 0.813 & 0.043 & $25.737^{* * *}$ \\
\hline \multirow{6}{*}{ Destination-related factor (D) } & D-1 & 1 & 0.827 & & \\
\hline & D-2 & 1.075 & 0.841 & 0.032 & $34.099 * * *$ \\
\hline & D-3 & 1.078 & 0.834 & 0.032 & $33.711^{* * *}$ \\
\hline & D-4 & 1.042 & 0.802 & 0.033 & $31.877^{* * *}$ \\
\hline & D-7 & 0.9 & 0.653 & 0.037 & $24.243 * * *$ \\
\hline & D-9 & 0.854 & 0.591 & 0.04 & $21.468^{* * *}$ \\
\hline \multirow{4}{*}{$\begin{array}{l}\text { Social atmosphere related to } \\
\text { overseas travel (S) }\end{array}$} & S-3 & 1 & 0.666 & & \\
\hline & S-5 & 1.082 & 0.727 & 0.053 & $20.564^{* * *}$ \\
\hline & S-6 & 0.919 & 0.604 & 0.052 & $17.731^{* * *}$ \\
\hline & S-7 & 0.977 & 0.645 & 0.052 & $18.74^{* * *}$ \\
\hline \multirow{12}{*}{$\begin{array}{l}\text { Level of aircraft/airport } \\
\text { management related to } \\
\text { infectious diseases (A) }\end{array}$} & A-2 & 1 & 0.784 & & \\
\hline & A-1 & 0.918 & 0.742 & 0.033 & $27.951^{* * *}$ \\
\hline & A-3 & 1.028 & 0.801 & 0.033 & $30.777^{* * *}$ \\
\hline & A-4 & 1.032 & 0.8 & 0.034 & $30.747^{* * *}$ \\
\hline & A-5 & 1.059 & 0.825 & 0.033 & $32.018 * * *$ \\
\hline & A-6 & 1.051 & 0.818 & 0.033 & $31.667^{* * *}$ \\
\hline & A-7 & 0.985 & 0.768 & 0.034 & $29.174^{* * *}$ \\
\hline & A-8 & 0.966 & 0.753 & 0.034 & $28.455^{* * *}$ \\
\hline & A-9 & 0.795 & 0.637 & 0.034 & $23.225 * * *$ \\
\hline & A-11 & 0.719 & 0.534 & 0.038 & $19.02^{* * *}$ \\
\hline & A-12 & 0.982 & 0.784 & 0.033 & $29.957^{* * *}$ \\
\hline & A-13 & 0.912 & 0.727 & 0.033 & $27.245^{* * *}$ \\
\hline
\end{tabular}

According to the structural model analysis per factor, the paths reaching from the COVID-19-related factors $(C)$ to the factor of self-isolation upon entry and departure $(\mathrm{Q})$, destination-related factor (D), social atmosphere towards overseas travel (S), and the level of aircraft/airport management related to infectious diseases (A) were analyzed as being $\mathrm{CR}=19.16, \mathrm{CR}=6.038, \mathrm{CR}=8.128$, and $\mathrm{CR}=1.832$, respectively. Critical ratio (CR) is the index used in the structural equation model which can investigate whether each variable is significant similar to the $t$-value in the regression model [47]. The path from factors of self-isolation upon entry and departure (Q) to the destination-related factors (D) was $C R=-2.192$, which had a negative $(-)$ impact, while the paths to the social atmosphere towards 
overseas travel (S) and the level of aircraft/airport management (A) were $C R=5.391$ and $C R=2.773$, respectively. In addition, the paths from destination-related factors (D) to social atmosphere (S) and level of aircraft/airport (A) were $C R=8.696$ and $C R=10.109$, respectively. The path from social atmosphere related to overseas travel $(S)$ to the level of aircraft/airport management was confirmed at $C R=8.61$. The value of $\beta$ for the 'From $C$ to $Q^{\prime}$, 'From $C$ to $D^{\prime}$, 'From $C$ to $S^{\prime}$, or 'From $S$ to $A$ ' paths was 0.35 or above and the P-value of C.R. was less than 0.01 , indicating statistically significant results.

The path in which the value of the standardized coefficient $(\beta)$ was the most meaningful in the structural model per factor (Table 3) was the COVID-19-related factor (C) and the factor related to self-isolation upon entry and departure $(\mathrm{Q})$. As a result, it is reasonable to interpret that if we recover from COVID-19 early and many countries lift their self-isolation requirements for people entering, the possibility of resuming air travel also rises. The standardization coefficient $(\beta)$ value of the structural model (path) per factor for the factors of self-isolation upon entry and departure $(\mathrm{Q})$ and destination-related factors (D) was negative, thus the self-isolation factors $(Q)$ and destination-related factors (D) have conflicting effects. For example, the $\mathrm{Q} \rightarrow \mathrm{D}$ path indicates that even if more countries lift their mandatory self-isolation rules, but the circumstances at the destination are not good, it is likely to negatively affect the resumption of air travel. The standardized coefficients with positive values derived from this study have greater effects if the predisposing factor has an identical effect on the precipitating factor, and a negative value indicates that when the precipitating factor's effect is aligned in the opposite direction as the predisposing factor, the oppositional effect due to the precipitating factor is great.

Table 3. Analysis of structural model (paths) per factor.

\begin{tabular}{|c|c|c|c|c|c|c|}
\hline & \multirow{2}{*}{\multicolumn{2}{|c|}{ Factor }} & \multicolumn{2}{|c|}{ Estimate } & \multirow{2}{*}{ S.E. } & \multirow{2}{*}{ C.R. } \\
\hline & & & B & $\beta$ & & \\
\hline $\begin{array}{l}\text { COVID-19-related } \\
\text { factor (C) }\end{array}$ & $->$ & $\begin{array}{l}\text { Factor related to self-isolation } \\
\text { upon entry and departure }(Q)\end{array}$ & 0.771 & 0.777 & 0.04 & $19.16^{* * *}$ \\
\hline $\begin{array}{l}\text { COVID-19-related } \\
\text { factor (C) }\end{array}$ & $->$ & Destination-related factor (D) & 0.345 & 0.363 & 0.057 & $6.038^{* * *}$ \\
\hline $\begin{array}{l}\text { COVID-19-related } \\
\text { factor }(C)\end{array}$ & $->$ & $\begin{array}{c}\text { Social atmosphere related to } \\
\text { overseas travel (S) }\end{array}$ & 0.427 & 0.446 & 0.052 & $8.128^{* * *}$ \\
\hline $\begin{array}{l}\text { COVID-19-related } \\
\text { factor }(C)\end{array}$ & $->$ & $\begin{array}{l}\text { Level of aircraft/airport } \\
\text { management related to } \\
\text { infectious diseases (A) }\end{array}$ & 0.104 & 0.092 & 0.057 & $1.832 *$ \\
\hline $\begin{array}{c}\text { Factor related to } \\
\text { self-isolation upon } \\
\text { entry and departure }(\mathrm{Q})\end{array}$ & $->$ & Destination-related factor (D) & -0.123 & -0.129 & 0.056 & $-2.192 * *$ \\
\hline $\begin{array}{c}\text { Factor related to } \\
\text { self-isolation upon } \\
\text { entry and departure }(\mathrm{Q})\end{array}$ & $->$ & $\begin{array}{l}\text { Social atmosphere related to } \\
\text { overseas travel (S) }\end{array}$ & 0.266 & 0.276 & 0.049 & $5.391 * * *$ \\
\hline $\begin{array}{c}\text { Factor related to } \\
\text { self-isolation upon } \\
\text { entry and departure (Q) }\end{array}$ & $->$ & $\begin{array}{l}\text { Level of aircraft/airport } \\
\text { management related to } \\
\text { infectious diseases (A) }\end{array}$ & 0.141 & 0.124 & 0.051 & $2.773 * * *$ \\
\hline $\begin{array}{l}\text { Destination-related } \\
\text { factor (D) }\end{array}$ & $->$ & $\begin{array}{l}\text { Social atmosphere related to } \\
\text { overseas travel (S) }\end{array}$ & 0.255 & 0.254 & 0.029 & $8.696^{* * *}$ \\
\hline $\begin{array}{l}\text { Destination-related } \\
\text { factor (D) }\end{array}$ & $->$ & $\begin{array}{l}\text { Level of aircraft/airport } \\
\text { management related to } \\
\text { infectious diseases (A) }\end{array}$ & 0.337 & 0.283 & 0.033 & $10.109^{* * *}$ \\
\hline $\begin{array}{l}\text { Social atmosphere } \\
\text { related to overseas } \\
\text { travel }(\mathrm{S})\end{array}$ & $->$ & $\begin{array}{l}\text { Level of aircraft/airport } \\
\text { management related to } \\
\text { infectious diseases (A) }\end{array}$ & 0.532 & 0.449 & 0.062 & $8.61^{* * *}$ \\
\hline
\end{tabular}

Moreover, we checked construct reliability and average variance extracted (AVE, known as the Fornell-Larcker approach) for reliability analysis and validity test. All factors are determined to satisfy 
the criteria that composite reliability (construct reliability) is over 0.7 , average variance extracted is over 0.5.

\section{Conclusions}

This study confirmed that self-isolation, destination, preventive measures combating infectious diseases in the aviation sector, and social perceptions towards overseas travel all influence the decision to resume air travel, in addition to the changes in the state of the COVID-19 pandemic. As of August 2020 , uncertainty regarding the prevalence of COVID-19 and the development of a vaccine or cure is very high [48]. Nevertheless, discussions are ongoing in international organizations, governments, and the aviation industry regarding how to recover a sustainable aviation demand. In addition to the factors directly associated with COVID-19, it was confirmed that the other four factors in this paper are significantly factored into passengers' decision to travel by air again. By identifying the structural path of these factors and then developing a valid survey form, we are able to present meaningful implications for the formulation of a strategy to recover aviation demand.

This study found that, even if a cure or vaccine was not developed for COVID-19, if the other four factors (requirements for self-isolation, circumstances at the destination, social atmosphere with regards to overseas travel, and level of disinfection measures employed in the aviation service sector) satisfy certain conditions, the possibility of resuming air travel would increase, so long as the number of new confirmed cases remains stable. In particular, we found that easing the requirements for self-isolation after factors related to the prevalence of COVID-19 have been reduced, such as a decrease in the number of new confirmed COVID-19 cases, could increase the possibility of resuming air travel. These findings indicate that aviation demand may increase if the requirements for self-isolation are eased and the prevalence of COVID-19 is moderately reduced. This serves as indirect evidence that the effort to attenuate lockdown measures between countries where the prevalence of COVID-19 has been reduced and cutting back on self-isolation requirements would be effective in recovering demand for air travel, from the sustainability perspective.

Although the effectiveness would be different than easing the requirements for self-isolation, it was estimated that a positive change in the social atmosphere regarding overseas travel along with a reduced prevalence of COVID-19 would also increase the likelihood of a recovery in aviation demand. These results reflect a social reluctance to travel due to fear of the transmission of the infectious disease considering current circumstances, and a social consensus is required to recover aviation demand. While the prevalence of COVID-19 remains low, the level of preventive measures at the airport and aircraft against infectious diseases has a meaningful effect on the decision to resume air travel, but it has less of a synergistic effect when compared to the other three factors.

If the circumstances at the destination are not good, even if the requirements for self-isolation are eased, it was found to have a negative influence on the prospects of recovering aviation demand. This indicates that an unconditional lifting of self-isolation requirements while the circumstances at the destination remains bad could have a negative effect on the recovery of aviation demand as well as control of the pandemic. At the national level, the ideal policy direction is to prioritize general sanitary conditions associated with COVID-19. The structural paths between factors for a meaningful recovery in aviation demand have been identified, which will enable short-term policy changes to help recover aviation demand.

A variety of surveys to examine the five factors established in this study also confirmed the degree to which each factor affects recovery of aviation demand, post COVID-19. This is because the individual factors reflect the severity of various circumstances associated with COVID-19, enabling the derivation of the importance of questions about each of the factors. For example, COVID-19-related factors demonstrate that the question about traveling overseas if the number of new confirmed COVID-19 cases per day falls below 50 is more important than the development of a cure or vaccine. This indicates that a fall in the number of new confirmed cases could affect the recovery of aviation demand prior to the development of a cure or vaccine. 
We investigated the air transport passenger behavior change after COVID-19, to supplement the previous studies such as demand change from the macro perspective [38] and behavior change in the local impact case [39]. Even though it is very important that the cause should be solved, we found that combined factors could positively change passengers' perceptions on resuming use of air transport. This finding may be contributed to provide the theoretical basis to those who want to pump up the aviation industry sustainability even in this pandemic through strategies such as travel bubbles [49].

The survey in this paper was focused on South Korea, and parameters would be adjusted according to the context of implementations in other cases. If uncertainty related with COVID-19 [48] fundamentally changes the supply chain sustainability in aviation industry, the result may be biased. Further studies would be needed to validate the suggested model transferability based on empirical cases and consider the supply change caused by COVID-19 and the effect on passengers' behaviors.

Based on the results of this survey conducted for the case of Korea, the study was able to derive a survey for the post-COVID-19 resumption of air travel. In terms of aviation demand sustainability, COVID-19 is an unprecedented crisis, thus the air travel behaviors of passengers, and how they might change, is highly uncertain after the pandemic. We hope that the results and questionnaire derived from this study will serve as a starting point for subsequent studies to help mitigate uncertainty and for the formulation of effective strategies for recovering aviation demand which will have to be backed by studies that monitor the behaviors of passengers.

Author Contributions: Conceptualization, K.-H.S.; methodology, K.-H.S. and S.C.; software, K.-H.S. and S.C.; investigation, S.C.; resources, S.C.; formal analysis, K.-H.S. and S.C.; data curation, S.C.; writing-original draft preparation, S.C. and K.-H.S.; writing-review and editing, K.-H.S. and S.C.; supervision, K.-H.S.; project administration K.-H.S. All authors have read and agreed to the published version of the manuscript.

Funding: This study was funded by Korea Transport Institute for its task to "Research project for enhancement of airport competitiveness and regional development in Korea by the year 2020", grant number 31-20-014 And The APC was funded by Korea Transport Institute.

Conflicts of Interest: The authors declare no conflict of interest.

\section{Appendix A. Survey Questions in Study}

Table A1. Survey Questions in Study.

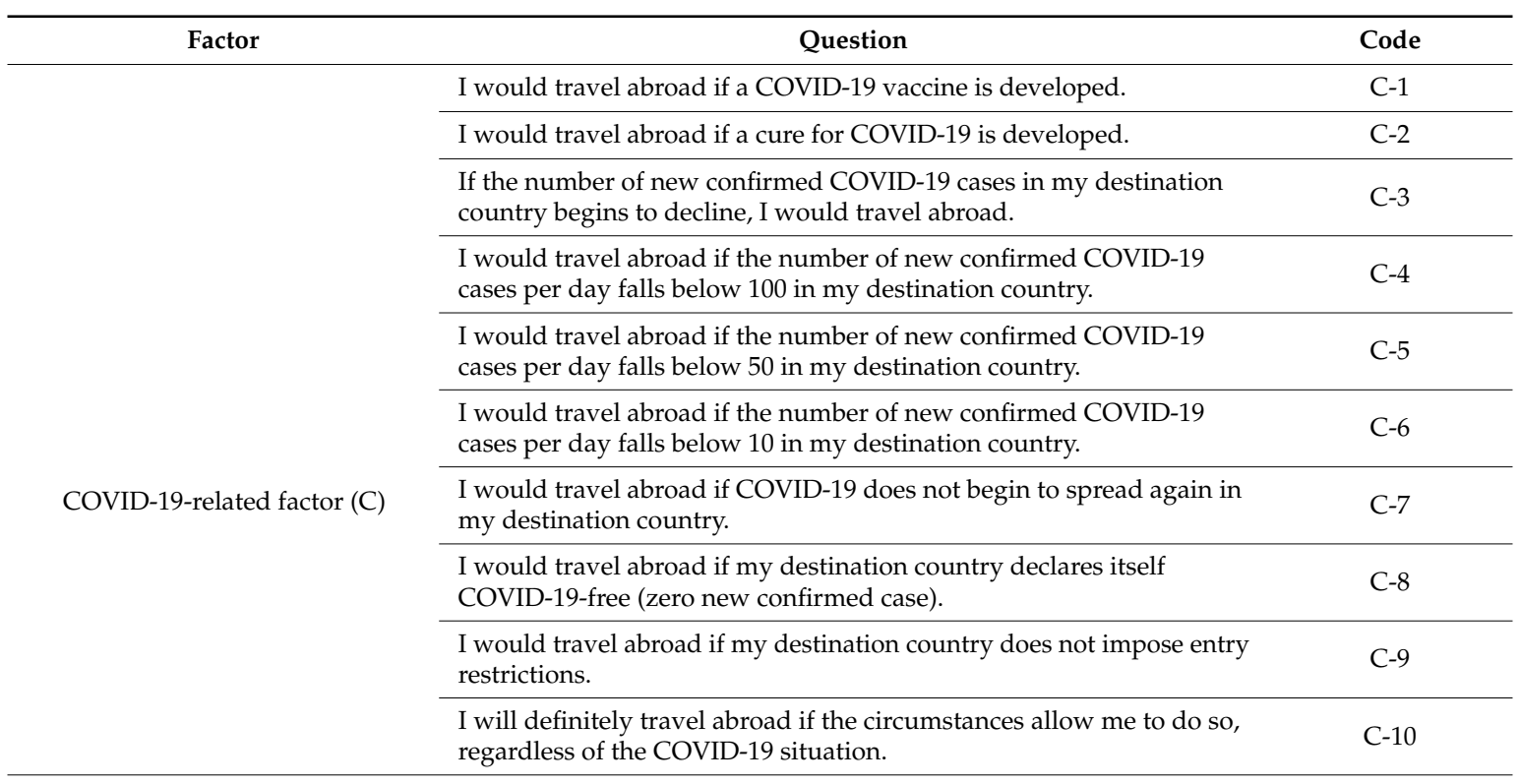


Table A1. Cont.

\begin{tabular}{|c|c|c|}
\hline Factor & Question & Code \\
\hline \multirow{5}{*}{$\begin{array}{l}\text { Factor related to self-isolation } \\
\text { upon entry and departure }(\mathrm{Q})\end{array}$} & $\begin{array}{l}\text { I would travel abroad if there were no entry restrictions, } \\
\text { even if I have to self-isolate (currently } 14 \text { days) upon } \\
\text { arrival. }\end{array}$ & Q-1 \\
\hline & $\begin{array}{l}\text { I would travel abroad if the self-isolation period was } \\
\text { reduced to } 2 \text { weeks or less (currently } 14 \text { days) upon } \\
\text { arrival. }\end{array}$ & Q-2 \\
\hline & $\begin{array}{l}\text { I would travel abroad if the self-isolation period was } \\
\text { reduced to } 1 \text { week or less (currently } 14 \text { days) upon } \\
\text { arrival. }\end{array}$ & Q-3 \\
\hline & $\begin{array}{l}\text { I would travel abroad if self-isolation was no longer } \\
\text { required. }\end{array}$ & Q-4 \\
\hline & $\begin{array}{l}\text { I will definitely travel abroad if the circumstances allow } \\
\text { me to do so, regardless of self-isolation. }\end{array}$ & Q-5 \\
\hline \multirow{10}{*}{ Destination-related factor (D) } & $\begin{array}{l}\text { I would travel abroad if the sanitary conditions of tourist } \\
\text { attractions in my destination country were good. }\end{array}$ & D-1 \\
\hline & $\begin{array}{l}\text { I would travel abroad if the sanitary conditions of } \\
\text { accommodation facilities in my destination country were } \\
\text { good. }\end{array}$ & D-2 \\
\hline & $\begin{array}{l}\text { I would travel abroad if the sanitary conditions of } \\
\text { restaurants in my destination country were good. }\end{array}$ & D-3 \\
\hline & $\begin{array}{l}\text { I would travel abroad if the sanitary conditions of public } \\
\text { transportation in my destination country were good. }\end{array}$ & D-4 \\
\hline & $\begin{array}{l}\text { I would travel abroad if the climate in my destination } \\
\text { country was hot. }\end{array}$ & D-5 \\
\hline & $\begin{array}{l}\text { I would travel abroad if the climate in my destination } \\
\text { country was cold. }\end{array}$ & D-6 \\
\hline & $\begin{array}{l}\text { I would travel abroad if it is convenient to use the } \\
\text { medical facilities (hospitals and pharmacies) in my } \\
\text { destination country. }\end{array}$ & D-7 \\
\hline & $\begin{array}{l}\text { I would travel abroad if my destination country has few } \\
\text { international tourists (or if my destination country } \\
\text { restricts the number of tourists allowed to enter per day). }\end{array}$ & D-8 \\
\hline & $\begin{array}{l}\text { I would travel abroad if the leisure or sports (activities) } \\
\text { available in my destination country was were managed } \\
\text { in a sanitary way. }\end{array}$ & D-9 \\
\hline & $\begin{array}{l}\text { I will definitely travel abroad if the circumstances allow } \\
\text { me to do so, regardless of the country's condition. }\end{array}$ & D-10 \\
\hline \multirow{7}{*}{$\begin{array}{l}\text { Social atmosphere related to } \\
\quad \text { overseas travel }(S)\end{array}$} & $\begin{array}{l}\text { I would travel abroad if social perception regarding } \\
\text { overseas travel improves to a point better than it is } \\
\text { currently. }\end{array}$ & S-1 \\
\hline & $\begin{array}{l}\text { I would travel abroad if social perception regarding } \\
\text { overseas travel recovers to the pre-COVID-19 level. }\end{array}$ & S-2 \\
\hline & $\begin{array}{l}\text { If people around me are traveling abroad, I will also } \\
\text { travel abroad. }\end{array}$ & S-3 \\
\hline & $\begin{array}{l}\text { I would travel abroad if there was no fear regarding } \\
\text { contracting (transmitting) COVID-19 due to overseas } \\
\text { travel. }\end{array}$ & S-4 \\
\hline & $\begin{array}{l}\text { I would travel abroad if the government did not restrict } \\
\text { overseas travel. }\end{array}$ & S-5 \\
\hline & $\begin{array}{l}\text { I would travel abroad if the World Health Organization } \\
\text { (WHO) said it was okay to travel abroad. }\end{array}$ & S-6 \\
\hline & $\begin{array}{l}\text { I will definitely travel abroad if the circumstances allow } \\
\text { me to do so, regardless of the perceptions of the people } \\
\text { around me. }\end{array}$ & S-7 \\
\hline
\end{tabular}


Table A1. Cont.

\begin{tabular}{|c|c|c|}
\hline Factor & Question & Code \\
\hline \multirow{13}{*}{$\begin{array}{l}\text { Level of aircraft/airport } \\
\text { management related to } \\
\text { infectious diseases (A) }\end{array}$} & $\begin{array}{l}\text { I would travel abroad by air if the airline seats remain } \\
\text { distanced from each other ( } 1 \mathrm{~m} \text { or more). }\end{array}$ & A-1 \\
\hline & $\begin{array}{l}\text { I would travel abroad by air if sufficient management is } \\
\text { carried out regarding preventive measures, such as } \\
\text { restricting the number of flights per day. }\end{array}$ & A-2 \\
\hline & $\begin{array}{l}\text { I would travel abroad by air if the sanitary conditions } \\
\text { (provision of hand sanitizer and other disinfection } \\
\text { measures) within the aircraft improve. }\end{array}$ & A-3 \\
\hline & $\begin{array}{l}\text { I would travel abroad again by air if aircraft were } \\
\text { equipped with apparatuses to prevent transmission of } \\
\text { disease through the air or via droplets, such as seat } \\
\text { partitions, etc. }\end{array}$ & A-4 \\
\hline & $\begin{array}{l}\text { I would travel abroad by air if all airport employees and } \\
\text { cabin crew wore face masks. }\end{array}$ & A-5 \\
\hline & $\begin{array}{l}\text { I would travel abroad by air if preventive measures were } \\
\text { regularly carried out in all airport facilities. }\end{array}$ & A-6 \\
\hline & $\begin{array}{l}\text { I would travel abroad by air if COVID-19 testing was } \\
\text { conducted on all passengers upon departure or entry. }\end{array}$ & A-7 \\
\hline & $\begin{array}{l}\text { I would travel abroad by air if direct flights were } \\
\text { available for me to travel to my destination. }\end{array}$ & A-8 \\
\hline & $\begin{array}{l}\text { Even if a layover is needed to arrive at my destination, I } \\
\text { would travel abroad by air if I only have to stay inside } \\
\text { the airport. }\end{array}$ & A-9 \\
\hline & $\begin{array}{l}\text { I will definitely travel abroad if the circumstances allow } \\
\text { me to do so, regardless of the aircraft/airport } \\
\text { circumstances. }\end{array}$ & A-10 \\
\hline & $\begin{array}{l}\text { I would travel abroad by air if I don't have to wear a face } \\
\text { mask inside the aircraft (if I can breathe freely). }\end{array}$ & A-11 \\
\hline & $\begin{array}{l}\text { I would travel abroad by air if a distance ( } 1 \mathrm{~m} \text { or more) is } \\
\text { maintained between people for check-in, security check, } \\
\text { and boarding. }\end{array}$ & A-12 \\
\hline & $\begin{array}{l}\text { I would travel abroad by air if the public transportation } \\
\text { (trains and buses) used to access the airport do not get } \\
\text { crowded. }\end{array}$ & A-13 \\
\hline
\end{tabular}

\section{Appendix B. Survey Results}

Table A2. Survey results for COVID-19-related factors (C).

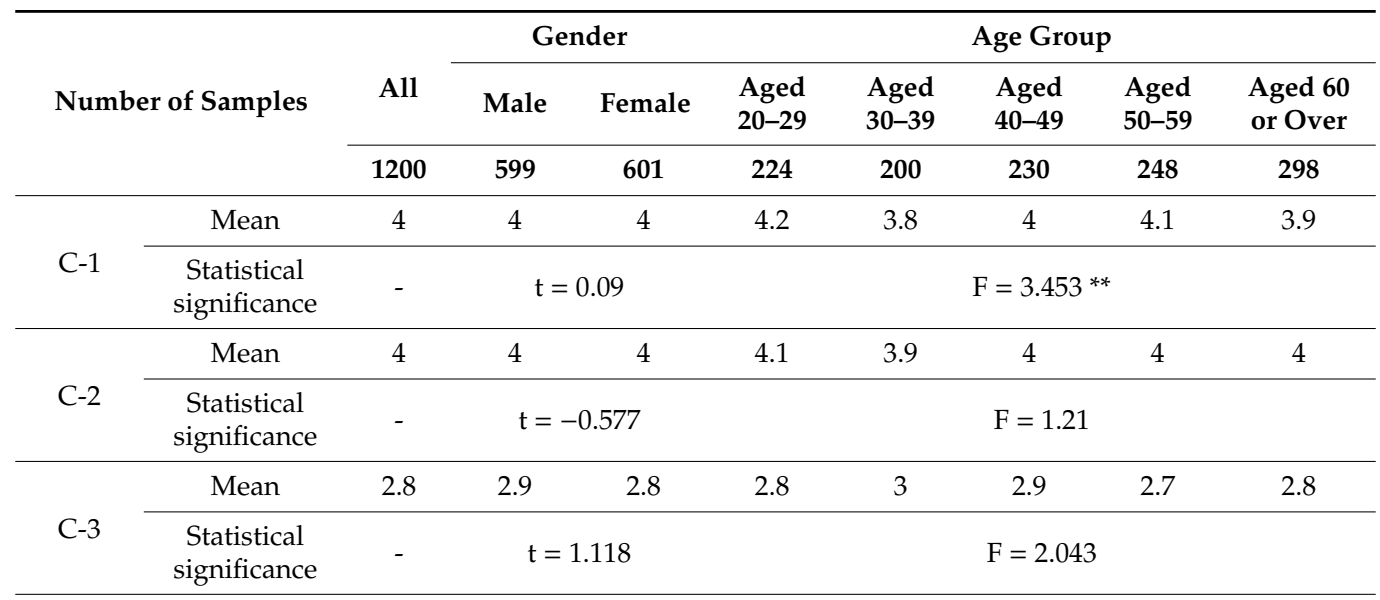


Table A2. Cont.

\begin{tabular}{|c|c|c|c|c|c|c|c|c|c|}
\hline \multirow{2}{*}{\multicolumn{2}{|c|}{ Number of Samples }} & \multirow{2}{*}{$\begin{array}{c}\text { All } \\
1200\end{array}$} & \multicolumn{2}{|c|}{ Gender } & \multicolumn{5}{|c|}{ Age Group } \\
\hline & & & $\begin{array}{c}\text { Male } \\
599\end{array}$ & $\begin{array}{c}\text { Female } \\
601\end{array}$ & $\begin{array}{c}\text { Aged } \\
20-29 \\
224\end{array}$ & $\begin{array}{c}\text { Aged } \\
30-39 \\
200\end{array}$ & $\begin{array}{c}\text { Aged } \\
40-49 \\
230 \\
\end{array}$ & $\begin{array}{c}\text { Aged } \\
50-59 \\
248 \\
\end{array}$ & $\begin{array}{c}\begin{array}{c}\text { Aged } 60 \\
\text { or Over }\end{array} \\
298 \\
\end{array}$ \\
\hline \multirow[b]{2}{*}{ C-4 } & Mean & 2 & 2 & 2 & 2.1 & 2.3 & 2 & 1.8 & 1.9 \\
\hline & $\begin{array}{c}\text { Statistical } \\
\text { significance }\end{array}$ & - & \multicolumn{2}{|c|}{$\mathrm{t}=0.214$} & \multicolumn{5}{|c|}{$\mathrm{F}=6.11^{* * *}$} \\
\hline \multirow[b]{2}{*}{$C-5$} & Mean & 2.2 & 2.3 & 2.2 & 2.2 & 2.5 & 2.3 & 2.1 & 2.1 \\
\hline & $\begin{array}{c}\text { Statistical } \\
\text { significance }\end{array}$ & - & \multicolumn{2}{|c|}{$t=1.773$} & \multicolumn{5}{|c|}{$\mathrm{F}=4.248^{* *}$} \\
\hline \multirow[b]{2}{*}{$C-6$} & Mean & 2.8 & 2.8 & 2.7 & 2.8 & 2.9 & 2.8 & 2.6 & 2.8 \\
\hline & $\begin{array}{l}\text { Statistical } \\
\text { significance }\end{array}$ & - & \multicolumn{2}{|c|}{$t=1.143$} & \multicolumn{5}{|c|}{$F=1.582$} \\
\hline \multirow[b]{2}{*}{ C-7 } & Mean & 3.1 & 3 & 3.2 & 3.3 & 3 & 3 & 3 & 3 \\
\hline & $\begin{array}{l}\text { Statistical } \\
\text { significance }\end{array}$ & - & \multicolumn{2}{|c|}{$\mathrm{t}=-2.26^{*}$} & \multicolumn{5}{|c|}{$\mathrm{F}=2.576^{*}$} \\
\hline \multirow[b]{2}{*}{ C-8 } & Mean & 3.8 & 3.8 & 3.9 & 4 & 3.7 & 3.7 & 3.9 & 3.8 \\
\hline & $\begin{array}{c}\text { Statistical } \\
\text { significance }\end{array}$ & - & \multicolumn{2}{|c|}{$\mathrm{t}=-1.145$} & \multicolumn{5}{|c|}{$\mathrm{F}=3.127 *$} \\
\hline \multirow[b]{2}{*}{ C-9 } & Mean & 2.8 & 2.9 & 2.8 & 2.9 & 2.8 & 2.9 & 2.8 & 2.8 \\
\hline & $\begin{array}{l}\text { Statistical } \\
\text { significance }\end{array}$ & - & \multicolumn{2}{|c|}{$\mathrm{t}=0.52$} & \multicolumn{5}{|c|}{$F=0.682$} \\
\hline \multirow[b]{2}{*}{ C-10 } & Mean & 2.1 & 2.1 & 2.1 & 2.1 & 2.2 & 2.2 & 2 & 2 \\
\hline & $\begin{array}{l}\text { Statistical } \\
\text { significance }\end{array}$ & - & \multicolumn{2}{|c|}{$t=0.671$} & \multicolumn{5}{|c|}{$F=1.166$} \\
\hline
\end{tabular}

Table A3. Survey results for destination factors (Q).

\begin{tabular}{|c|c|c|c|c|c|c|c|c|c|}
\hline \multirow{2}{*}{\multicolumn{2}{|c|}{ Number of Samples }} & \multirow{2}{*}{$\begin{array}{c}\text { All } \\
1200 \\
\end{array}$} & \multicolumn{2}{|c|}{ Gender } & \multicolumn{5}{|c|}{ Age Group } \\
\hline & & & $\begin{array}{c}\text { Male } \\
599 \\
\end{array}$ & $\begin{array}{c}\text { Female } \\
601\end{array}$ & $\begin{array}{c}\text { Aged } \\
20-29\end{array}$ & $\begin{array}{c}\begin{array}{c}\text { Aged } \\
30-39\end{array} \\
200\end{array}$ & 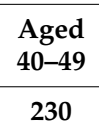 & $\begin{array}{c}\begin{array}{c}\text { Aged } \\
50-59\end{array} \\
248 \\
\end{array}$ & $\begin{array}{c}\begin{array}{c}\text { Aged } 60 \\
\text { or Over }\end{array} \\
298 \\
\end{array}$ \\
\hline \multirow[b]{2}{*}{ Q-1 } & Mean & 2.1 & 2.2 & 2 & 2.2 & 2.4 & 2.1 & 2 & 1.9 \\
\hline & $\begin{array}{c}\text { Statistical } \\
\text { significance }\end{array}$ & - & \multicolumn{2}{|c|}{$t=2.461^{*}$} & \multicolumn{5}{|c|}{$\mathrm{F}=6.316^{* * *}$} \\
\hline \multirow[b]{2}{*}{ Q-2 } & Mean & 2 & 2 & 2 & 2.1 & 2.3 & 2 & 1.8 & 1.9 \\
\hline & $\begin{array}{c}\text { Statistical } \\
\text { significance }\end{array}$ & - & \multicolumn{2}{|c|}{$\mathrm{t}=1.05$} & \multicolumn{5}{|c|}{$\mathrm{F}=5.825^{* * *}$} \\
\hline \multirow[b]{2}{*}{ Q-3 } & Mean & 2.1 & 2.2 & 2.1 & 2.1 & 2.4 & 2.2 & 2 & 2.1 \\
\hline & $\begin{array}{c}\text { Statistical } \\
\text { significance }\end{array}$ & - & \multicolumn{2}{|c|}{$\mathrm{t}=1.682$} & \multicolumn{5}{|c|}{$\mathrm{F}=3.55^{* *}$} \\
\hline \multirow[b]{2}{*}{ Q-4 } & Mean & 3.4 & 3.4 & 3.4 & 3.5 & 3.4 & 3.3 & 3.4 & 3.4 \\
\hline & $\begin{array}{c}\text { Statistical } \\
\text { significance }\end{array}$ & - & \multicolumn{2}{|c|}{$t=-0.225$} & \multicolumn{5}{|c|}{$\mathrm{F}=0.541$} \\
\hline \multirow[b]{2}{*}{ Q-5 } & Mean & 2.1 & 2.1 & 2 & 2 & 2.3 & 2.1 & 2 & 2 \\
\hline & $\begin{array}{c}\text { Statistical } \\
\text { significance }\end{array}$ & - & \multicolumn{2}{|c|}{$t=1.619$} & \multicolumn{5}{|c|}{$\mathrm{F}=2.787^{*}$} \\
\hline
\end{tabular}


Table A4. Survey results for destination factors (D).

\begin{tabular}{|c|c|c|c|c|c|c|c|c|c|}
\hline \multirow{2}{*}{\multicolumn{2}{|c|}{ Number of Samples }} & \multirow{2}{*}{$\begin{array}{c}\text { All } \\
1200 \\
\end{array}$} & \multicolumn{2}{|c|}{ Gender } & \multicolumn{5}{|c|}{ Age Group } \\
\hline & & & $\begin{array}{c}\text { Male } \\
599\end{array}$ & $\begin{array}{c}\text { Female } \\
601\end{array}$ & $\begin{array}{c}\text { Aged } \\
20-29 \\
224\end{array}$ & $\begin{array}{c}\text { Aged } \\
30-39 \\
200 \\
\end{array}$ & $\begin{array}{c}\text { Aged } \\
40-49 \\
230 \\
\end{array}$ & $\begin{array}{c}\text { Aged } \\
50-59 \\
248\end{array}$ & $\begin{array}{c}\begin{array}{c}\text { Aged } 60 \\
\text { or Over }\end{array} \\
298 \\
\end{array}$ \\
\hline \multirow[b]{2}{*}{ D-1 } & Mean & 3.8 & 3.8 & 3.8 & 4 & 3.7 & 3.8 & 3.8 & 3.7 \\
\hline & $\begin{array}{l}\text { Statistical } \\
\text { significance }\end{array}$ & - & \multicolumn{2}{|c|}{$\mathrm{t}=-0.07$} & \multicolumn{5}{|c|}{$\mathrm{F}=3.272 *$} \\
\hline \multirow[b]{2}{*}{ D-2 } & Mean & 3.7 & 3.7 & 3.8 & 4 & 3.7 & 3.8 & 3.7 & 3.6 \\
\hline & $\begin{array}{l}\text { Statistical } \\
\text { significance }\end{array}$ & - & \multicolumn{2}{|c|}{$\mathrm{t}=-1.471$} & \multicolumn{5}{|c|}{$\mathrm{F}=4.85^{* * *}$} \\
\hline \multirow[b]{2}{*}{ D-3 } & Mean & 3.7 & 3.7 & 3.8 & 4 & 3.6 & 3.7 & 3.7 & 3.6 \\
\hline & $\begin{array}{c}\text { Statistical } \\
\text { significance }\end{array}$ & - & \multicolumn{2}{|c|}{$t=-1.376$} & \multicolumn{5}{|c|}{$\mathrm{F}=3.781^{* *}$} \\
\hline \multirow[b]{2}{*}{ D-4 } & Mean & 3.7 & 3.7 & 3.7 & 4 & 3.6 & 3.7 & 3.7 & 3.5 \\
\hline & $\begin{array}{l}\text { Statistical } \\
\text { significance }\end{array}$ & - & \multicolumn{2}{|c|}{$\mathrm{t}=-0.945$} & \multicolumn{5}{|c|}{$\mathrm{F}=6.26^{* * *}$} \\
\hline \multirow[b]{2}{*}{ D-5 } & Mean & 2.5 & 2.5 & 2.5 & 2.7 & 2.7 & 2.6 & 2.3 & 2.3 \\
\hline & $\begin{array}{l}\text { Statistical } \\
\text { significance }\end{array}$ & - & \multicolumn{2}{|c|}{$t=-0.125$} & \multicolumn{5}{|c|}{$\mathrm{F}=6.453^{* * *}$} \\
\hline \multirow[b]{2}{*}{ D-6 } & Mean & 2.5 & 2.6 & 2.5 & 2.9 & 2.6 & 2.6 & 2.4 & 2.3 \\
\hline & $\begin{array}{l}\text { Statistical } \\
\text { significance }\end{array}$ & - & \multicolumn{2}{|c|}{$t=0.864$} & \multicolumn{5}{|c|}{$\mathrm{F}=10.082 * * *$} \\
\hline \multirow[b]{2}{*}{ D-7 } & Mean & 3.5 & 3.5 & 3.6 & 3.9 & 3.5 & 3.5 & 3.5 & 3.4 \\
\hline & $\begin{array}{l}\text { Statistical } \\
\text { significance }\end{array}$ & - & \multicolumn{2}{|c|}{$\mathrm{t}=-0.873$} & \multicolumn{5}{|c|}{$\mathrm{F}=5.793^{* * *}$} \\
\hline \multirow[b]{2}{*}{ D-8 } & Mean & 2.9 & 2.8 & 2.9 & 3.2 & 3 & 3 & 2.7 & 2.6 \\
\hline & $\begin{array}{l}\text { Statistical } \\
\text { significance }\end{array}$ & - & $\mathrm{t}=$ & .335 & & & $=12.31$ & & \\
\hline & Mean & 3.3 & 3.3 & 3.3 & 3.7 & 3.3 & 3.4 & 3.1 & 3.1 \\
\hline D-9 & $\begin{array}{l}\text { Statistical } \\
\text { significance }\end{array}$ & - & $t=$ & .606 & & & $F=10.34$ & & \\
\hline & Mean & 2.3 & 2.3 & 2.3 & 2.4 & 2.5 & 2.3 & 2.2 & 2.2 \\
\hline D-10 & $\begin{array}{c}\text { Statistical } \\
\text { significance }\end{array}$ & - & & 059 & & & $\mathrm{~F}=2.0$ & & \\
\hline
\end{tabular}

Table A5. Survey results for social atmosphere related to overseas travel (S).

\begin{tabular}{|c|c|c|c|c|c|c|c|c|c|}
\hline & & \multirow[b]{2}{*}{ All } & \multicolumn{2}{|c|}{ Gender } & \multicolumn{5}{|c|}{ Age Group } \\
\hline \multicolumn{2}{|c|}{ Number of Samples } & & Male & Female & $\begin{array}{l}\text { Aged } \\
20-29\end{array}$ & $\begin{array}{l}\text { Aged } \\
30-39\end{array}$ & $\begin{array}{l}\text { Aged } \\
40-49\end{array}$ & $\begin{array}{l}\text { Aged } \\
50-59\end{array}$ & $\begin{array}{l}\text { Aged } 60 \\
\text { or Over }\end{array}$ \\
\hline & & 1200 & 599 & 601 & 224 & 200 & 230 & 248 & 298 \\
\hline \multirow[b]{2}{*}{ S-1 } & Mean & 3.4 & 3.4 & 3.4 & 3.7 & 3.4 & 3.4 & 3.3 & 3.3 \\
\hline & $\begin{array}{c}\text { Statistical } \\
\text { significance }\end{array}$ & - & \multicolumn{2}{|c|}{$\mathrm{t}=-0.334$} & \multicolumn{5}{|c|}{$\mathrm{F}=4.29 * *$} \\
\hline \multirow[b]{2}{*}{ S-2 } & Mean & 3.9 & 3.9 & 3.9 & 4 & 3.8 & 3.9 & 3.9 & 3.8 \\
\hline & $\begin{array}{c}\text { Statistical } \\
\text { significance }\end{array}$ & - & \multicolumn{2}{|c|}{$\mathrm{t}=-0.773$} & \multicolumn{5}{|c|}{$\mathrm{F}=1.353$} \\
\hline \multirow[b]{2}{*}{$\mathrm{S}-3$} & Mean & 2.8 & 2.8 & 2.8 & 3.1 & 3.1 & 2.8 & 2.7 & 2.6 \\
\hline & $\begin{array}{c}\text { Statistical } \\
\text { significance }\end{array}$ & - & \multicolumn{2}{|c|}{$\mathrm{t}=-0.373$} & \multicolumn{5}{|c|}{$\mathrm{F}=6.699^{* * *}$} \\
\hline
\end{tabular}


Table A5. Cont.

\begin{tabular}{|c|c|c|c|c|c|c|c|c|c|}
\hline \multirow{2}{*}{\multicolumn{2}{|c|}{ Number of Samples }} & \multirow{2}{*}{$\begin{array}{l}\text { All } \\
1200\end{array}$} & \multicolumn{2}{|c|}{ Gender } & \multicolumn{5}{|c|}{ Age Group } \\
\hline & & & $\begin{array}{c}\text { Male } \\
599\end{array}$ & $\begin{array}{c}\text { Female } \\
601\end{array}$ & $\begin{array}{c}\text { Aged } \\
20-29 \\
224\end{array}$ & $\begin{array}{c}\text { Aged } \\
30-39 \\
200\end{array}$ & $\begin{array}{c}\text { Aged } \\
40-49 \\
230 \\
\end{array}$ & $\begin{array}{c}\text { Aged } \\
50-59 \\
248 \\
\end{array}$ & $\begin{array}{c}\begin{array}{c}\text { Aged } 60 \\
\text { or Over }\end{array} \\
298 \\
\end{array}$ \\
\hline \multirow[b]{2}{*}{ S-4 } & Mean & 4 & 4 & 4 & 4.1 & 3.9 & 3.9 & 4.1 & 4 \\
\hline & $\begin{array}{c}\text { Statistical } \\
\text { significance }\end{array}$ & - & \multicolumn{2}{|c|}{$\mathrm{t}=-1.216$} & \multicolumn{5}{|c|}{$\mathrm{F}=1.871$} \\
\hline \multirow[b]{2}{*}{ S-5 } & Mean & 2.9 & 3 & 2.9 & 3 & 3.1 & 2.9 & 2.9 & 2.8 \\
\hline & $\begin{array}{c}\text { Statistical } \\
\text { significance }\end{array}$ & - & \multicolumn{2}{|c|}{$\mathrm{t}=0.826$} & \multicolumn{5}{|c|}{$\mathrm{F}=1.774$} \\
\hline \multirow[b]{2}{*}{ S-6 } & Mean & 3.2 & 3.1 & 3.2 & 3.2 & 3.3 & 3.1 & 3.2 & 3.2 \\
\hline & $\begin{array}{c}\text { Statistical } \\
\text { significance }\end{array}$ & - & \multicolumn{2}{|c|}{$\mathrm{t}=-1.729$} & \multicolumn{5}{|c|}{$\mathrm{F}=0.464$} \\
\hline \multirow[b]{2}{*}{ S-7 } & Mean & 2.2 & 2.3 & 2.2 & 2.3 & 2.5 & 2.3 & 2.3 & 2 \\
\hline & $\begin{array}{c}\text { Statistical } \\
\text { significance }\end{array}$ & - & \multicolumn{2}{|c|}{$\mathrm{t}=1.893$} & \multicolumn{5}{|c|}{$\mathrm{F}=3.793 * *$} \\
\hline
\end{tabular}

Table A6. Survey results for level of aircraft/airport management related to infectious diseases (A).

\begin{tabular}{|c|c|c|c|c|c|c|c|c|c|}
\hline \multirow{3}{*}{ 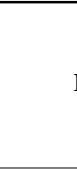 } & & \multirow{3}{*}{$\begin{array}{c}\text { All } \\
1,200\end{array}$} & \multicolumn{2}{|c|}{ Gender } & \multicolumn{5}{|c|}{ Age Group } \\
\hline & umber of Samples & & \multirow{2}{*}{$\begin{array}{c}\text { Male } \\
599\end{array}$} & \multirow{2}{*}{$\begin{array}{c}\text { Female } \\
601\end{array}$} & \multirow{2}{*}{$\begin{array}{c}\text { Aged } \\
20-29 \\
224 \\
\end{array}$} & \multirow{2}{*}{$\begin{array}{c}\text { Aged } \\
30-39 \\
200\end{array}$} & \multirow{2}{*}{$\begin{array}{c}\text { Aged } \\
40-49\end{array}$} & \multirow{2}{*}{$\begin{array}{c}\text { Aged } \\
50-59\end{array}$} & \multirow{2}{*}{$\begin{array}{c}\begin{array}{c}\text { Aged } 60 \\
\text { or Over }\end{array} \\
298\end{array}$} \\
\hline & & & & & & & & & \\
\hline \multirow[b]{2}{*}{ A-1 } & Mean & 2.9 & 2.9 & 2.9 & 3.1 & 2.9 & 2.8 & 2.9 & 2.8 \\
\hline & Statistical significance & - & \multicolumn{2}{|c|}{$\mathrm{t}=0.299$} & \multicolumn{5}{|c|}{$\mathrm{F}=2.576^{*}$} \\
\hline \multirow[b]{2}{*}{ A-2 } & Mean & 3 & 3.1 & 3 & 3.2 & 3.2 & 3 & 3 & 2.9 \\
\hline & Statistical significance & - & \multicolumn{2}{|c|}{$\mathrm{t}=0.433$} & \multicolumn{5}{|c|}{$\mathrm{F}=2.849^{*}$} \\
\hline \multirow[b]{2}{*}{ A-3 } & Mean & 3 & 3.1 & 2.9 & 3.3 & 3 & 3 & 2.9 & 2.8 \\
\hline & Statistical significance & - & \multicolumn{2}{|c|}{$\mathrm{t}=2.372^{*}$} & \multicolumn{5}{|c|}{$\mathrm{F}=5.732^{* * *}$} \\
\hline \multirow[b]{2}{*}{ A-4 } & Mean & 3.1 & 3.2 & 3.1 & 3.3 & 3.2 & 3.1 & 3.1 & 3.1 \\
\hline & Statistical significance & - & \multicolumn{2}{|c|}{$\mathrm{t}=0.544$} & \multicolumn{5}{|c|}{$\mathrm{F}=2.643 *$} \\
\hline \multirow[b]{2}{*}{ A-5 } & Mean & 2.9 & 2.9 & 2.9 & 3.3 & 3 & 2.9 & 2.8 & 2.7 \\
\hline & Statistical significance & - & \multicolumn{2}{|c|}{$\mathrm{t}=0.041$} & \multicolumn{5}{|c|}{$\mathrm{F}=9.674^{* * *}$} \\
\hline \multirow[b]{2}{*}{ A-6 } & Mean & 3.2 & 3.2 & 3.1 & 3.4 & 3.3 & 3.1 & 3 & 3 \\
\hline & Statistical significance & - & \multicolumn{2}{|c|}{$\mathrm{t}=0.345$} & \multicolumn{5}{|c|}{$\mathrm{F}=5.514^{* * *}$} \\
\hline & Mean & 3 & 3.1 & 3 & 3.3 & 3.1 & 3 & 3 & 2.9 \\
\hline A-7 & Statistical significance & - & & 085 & & & $=5.555$ & & \\
\hline & Mean & 3.1 & 3.2 & 3.1 & 3.4 & 3.2 & 3 & 3.1 & 3 \\
\hline A-8 & Statistical significance & - & & .57 & & & $=3.782$ & & \\
\hline & Mean & 2.6 & 2.7 & 2.5 & 2.9 & 2.7 & 2.5 & 2.5 & 2.5 \\
\hline A-9 & Statistical significance & - & $t=$ & $05^{* *}$ & & & $=4.786$ & & \\
\hline & Mean & 2.3 & 2.4 & 2.2 & 2.5 & 2.7 & 2.3 & 2.2 & 2.1 \\
\hline A-10 & Statistical significance & - & $t=$ & $355^{*}$ & & & $=6.001$ & & \\
\hline & Mean & 2.9 & 3 & 2.9 & 3.2 & 3.1 & 2.8 & 2.9 & 2.9 \\
\hline A-11 & Statistical significance & - & & 213 & & & $=3.00$ & & \\
\hline & Mean & 2.8 & 2.9 & 2.8 & 3.2 & 2.9 & 2.8 & 2.8 & 2.7 \\
\hline A-12 & Statistical significance & - & & .64 & & & $=5.113$ & & \\
\hline & Mean & 2.8 & 2.8 & 2.8 & 3.1 & 2.8 & 2.8 & 2.7 & 2.6 \\
\hline A-13 & Statistical significance & - & $t=$ & 173 & & & $=7.405$ & & \\
\hline
\end{tabular}




\section{Appendix C. Verified the Validity of Determination Using Correlation Coefficients and Standard Errors}

Note: Since 1 is not included in the range of correlation coefficients between all factors, it could be said that the validity of determination has been obtained.

Table A7. Verified the validity of determination using correlation coefficients and standard errors.

\begin{tabular}{|c|c|c|c|c|c|c|c|}
\hline & Category & & Estimate & S.E. & $\begin{array}{l}\text { S.E. }^{2} \text { le } 01 \\
\text { (two-tailed) }\end{array}$ & - & + \\
\hline $\begin{array}{l}\text { Level of } \\
\text { COVID-19 }\end{array}$ & $<->$ & $\begin{array}{l}\text { Self-isolation } \\
\text { period upon } \\
\text { entry }\end{array}$ & 0.777 & 0.039 & 0.078 & 0.699 & 0.855 \\
\hline $\begin{array}{l}\text { Level of } \\
\text { COVID-19 }\end{array}$ & $<->$ & $\begin{array}{l}\text { Circumstances } \\
\text { of overseas } \\
\text { destination }\end{array}$ & 0.263 & 0.025 & 0.05 & 0.213 & 0.313 \\
\hline $\begin{array}{c}\text { Level of } \\
\text { COVID-19 }\end{array}$ & $<->$ & $\begin{array}{c}\text { Social } \\
\text { atmosphere }\end{array}$ & 0.727 & 0.038 & 0.076 & 0.651 & 0.803 \\
\hline $\begin{array}{l}\text { Level of } \\
\text { COVID-19 }\end{array}$ & $<->$ & $\begin{array}{c}\text { Level of } \\
\text { aircraft/airport } \\
\text { management }\end{array}$ & 0.588 & 0.037 & 0.074 & 0.514 & 0.662 \\
\hline $\begin{array}{l}\text { Self-isolation } \\
\text { period } \\
\text { upon entry }\end{array}$ & $<->$ & $\begin{array}{c}\text { Circumstances } \\
\text { of overseas } \\
\text { destination }\end{array}$ & 0.153 & 0.024 & 0.048 & 0.105 & 0.201 \\
\hline $\begin{array}{l}\text { Self-isolation } \\
\text { period } \\
\text { upon entry }\end{array}$ & $<->$ & $\begin{array}{c}\text { Social } \\
\text { atmosphere }\end{array}$ & 0.661 & 0.036 & 0.072 & 0.589 & 0.733 \\
\hline $\begin{array}{l}\text { Self-isolation } \\
\text { period } \\
\text { upon entry }\end{array}$ & $<->$ & $\begin{array}{c}\text { Level of } \\
\text { aircraft/airport } \\
\text { management }\end{array}$ & 0.535 & 0.035 & 0.07 & 0.465 & 0.605 \\
\hline $\begin{array}{l}\text { Circumstances } \\
\text { of overseas } \\
\text { destination }\end{array}$ & $<->$ & $\begin{array}{c}\text { Social } \\
\text { atmosphere }\end{array}$ & 0.413 & 0.028 & 0.056 & 0.357 & 0.469 \\
\hline $\begin{array}{l}\text { Circumstances } \\
\text { of overseas } \\
\text { destination }\end{array}$ & $<->$ & $\begin{array}{c}\text { Level of } \\
\text { aircraft/airport } \\
\text { management }\end{array}$ & 0.512 & 0.031 & 0.062 & 0.45 & 0.574 \\
\hline $\begin{array}{c}\text { Social } \\
\text { atmosphere }\end{array}$ & $<->$ & $\begin{array}{c}\text { Level of } \\
\text { aircraft/airport } \\
\text { management }\end{array}$ & 0.714 & 0.041 & 0.082 & 0.632 & 0.796 \\
\hline
\end{tabular}

\section{References}

1. International Civil Aviation Organization. Effects of Novel Coronavirus (COVID-19) on Civil Aviation: Economic Impact Analysis. 2020. Available online: https://www.icao.int/sustainability/Documents/COVID19/ICAO_Coronavirus_Econ_Impact.pdf (accessed on 29 September 2020).

2. International Air Transport Association. IATA Economics' Chart of the Week-What Can We Learn from Past Pandemic Episodes? 2020. Available online: https://www.iata.org/en/iata-repository/publications/economicreports/what-can-we-learn-from-past-pandemic-episodes/ (accessed on 29 September 2020).

3. International Air Transport Association. Passenger Insights in the Times of a Pandemic Issue 1. 2020. Available online: https://www.iata.org/en/publications/store/covid-passenger-survey/ (accessed on 29 September 2020).

4. International Air Transport Association. Passenger Insights in the Times of a Pandemic Issue 2. 2020. Available online: https://www.iata.org/globalassets/iata/publications/iata-covid-19-pax-insights---issue-2--contents.pdf (accessed on 29 September 2020).

5. Dolnicar, S.; Grabler, K.; Grün, B.; Kulnig, A. Key drivers of airline loyalty. Tour. Manag. 2011, 32, $1020-1026$. [CrossRef] 
6. Ishii, J.; Jun, S.; Van Dender, K. Air travel choices in multi-airport markets. J. Urban Econ. 2009, 65, $216-227$. [CrossRef]

7. Verikios, G. The dynamic effects of infectious disease outbreaks: The case of pandemic influenza and human coronavirus. Socioecon. Plan. Sci. 2020, 71, 100898. [CrossRef]

8. Currie, G.M. A Lens on the Post-COVID-19 “New Normal” for Imaging Departments. J. Med. Imaging Radiat. Sci. 2020, 51, 361-363. [CrossRef]

9. Chen, H.-T.; Chao, C.-C. Airline choice by passengers from Taiwan and China: A case study of outgoing passengers from Kaohsiung International Airport. J. Air Transp. Manag. 2015, 49, 53-63. [CrossRef]

10. Mikulić, J.; Prebežac, D. What drives passenger loyalty to traditional and low-cost airlines? A formative partial least squares approach. J. Air Transp. Manag. 2011, 17, 237-240. [CrossRef]

11. Nako, S.M. Frequent Flyer Programs and Business Travellers: An Empirical Investigation. Logist. Transp. Rev. 1992, 28, 395-414.

12. Ong, W.L.; Tan, A.K.G. A note on the determinants of airline choice: The case of Air Asia and Malaysia Airlines. J. Air Transp. Manag. 2010, 16, 209-212. [CrossRef]

13. Yoo, K.E.; Ashford, N. Carrier Choices of Air Passengers in Pacific Rim: Using Comparative Analysis and Complementary Interpretation of Revealed Preference and Stated Preference Data. Transp. Res. Rec. 1996, 1562, 1-7. [CrossRef]

14. Innes, J.D.; Doucet, D.H. Effects of Access Distance and Level of Service on Airport Choice. J. Transp. Eng. 1990, 116, 507-516. [CrossRef]

15. Skinner, R.E. Airport choice: An empirical study. J. Transp. Eng. 1976, 102, 871-882.

16. Suzuki, Y. Modeling and testing the "two-step" decision process of travelers in airport and airline choices. Transp. Res. Part E Logist. Transp. Rev. 2007, 43, 1-20. [CrossRef]

17. Windle, R.; Dresner, M. Airport Choice in Multiple-Airport Regions. J. Transp. Eng. 1995, 121, $332-337$. [CrossRef]

18. McFadden, D. The measurement of urban travel demand. J. Public Econ. 1974, 3, 303-328. [CrossRef]

19. McFadden, D.; Train, K. Mixed MNL models for discrete response. J. Appl. Econom. 2000, 15, 447-470. [CrossRef]

20. Revelt, D.; Train, K. Mixed Logit with Repeated Choices: Households' Choices of Appliance Efficiency Level. Rev. Econ. Stat. 1998, 80, 647-657. [CrossRef]

21. Fornell, C.; Larker, D.F. Evaluating structural equation models with unobservable variables and measurement error. J. Mark. Res. 1981, 18, 39-50. [CrossRef]

22. Fornell, C.; Tellis, G.J.; Zinkhan, G.M. Validity Assessment: A Structural Equations Approach Using Partial Least Squares. Proc. Am. Mark. Assoc. Educ. Conf. 1982, 2.

23. Kline, R.B. Principles and Practice of Structural Equation Modeling, 4th ed.; Guilford Press: New York, NY, USA, 1998.

24. Lucini, F.R.; Tonetto, L.M.; Fogliatto, F.S.; Anzanello, M.J. Text mining approach to explore dimensions of airline customer satisfaction using online customer reviews. J. Air Transp. Manag. 2020, 83, 101760. [CrossRef]

25. Lee, G.; Lee, C.-K. Cross-cultural comparison of the image of Guam perceived by Korean and Japanese leisure travelers: Importance-performance analysis. Tour. Manag. 2009, 30, 922-931. [CrossRef]

26. Pels, E.; Nijkamp, P.; Rietveld, P. Airport and Airline Choice in a Multiple Airport Region: An Empirical Analysis for the San Francisco Bay Area. Reg. Stud. 2001, 35, 1-9. [CrossRef]

27. Lee, J.-K.; Yoo, K.E.; Song, K.-H. A study on travelers' transport mode choice behavior using the mixed logit model: A case study of the Seoul-Jeju route. J. Air Transp. Manag. 2016, 56, 131-137. [CrossRef]

28. Kelloway, E.K. Using LISREL for Structural Equation Modeling: A Researcher's Guide, 1st ed.; SAGE Publications: Thousand Oaks, CA, USA, 1998.

29. Ullman, J.B.; Bentler, P.M. Structural Equation Modeling, 2nd ed.; SAGE Publications: Thousand Oaks, CA, USA, 2006.

30. Forgas, S.; Palau, R.; Sánchez, J.; Huertas-Garcia, R.; Coll, S.F. Online drivers and offline influences related to loyalty to airline websites. J. Air Transp. Manag. 2012, 18, 43-46. [CrossRef]

31. Chiou, Y.-C.; Chen, Y.-H. Factors influencing the intentions of passengers regarding full service and low cost carriers: A note. J. Air Transp. Manag. 2010, 16, 226-228. [CrossRef] 
32. Yang, K.-C.; Hsieh, T.-C.; Li, H.; Yang, C. Assessing how service quality, airline image and customer value affect the intentions of passengers regarding low cost carriers. J. Air Transp. Manag. 2012, 20, 52-53. [CrossRef]

33. Martín-Consuegra, D.; Esteban, A.; Navarro, D.M.-C. Market orientation and business performance: An empirical investigation in the airline industry. J. Air Transp. Manag. 2007, 13, 383-386. [CrossRef]

34. Jenatabadi, H.S.; Ismail, N.A. Application of structural equation modelling for estimating airline performance. J. Air Transp. Manag. 2014, 40, 25-33. [CrossRef]

35. Bogicevic, V.; Yang, W.; Cobanoglu, C.; Bilgihan, A.; Bujisic, M. Traveler anxiety and enjoyment: The effect of airport environment on traveler's emotions. J. Air Transp. Manag. 2016, 57, 122-129. [CrossRef]

36. Han, H. Effects of in-flight ambience and space/function on air travelers' decision to select a low-cost airline. Tour. Manag. 2013, 37, 125-135. [CrossRef]

37. Wang, H.-L. Perception of safety culture: Surveying the aviation divisions of Ministry of National Defense, Taiwan, Republic of China. Saf. Sci. 2018, 108, 104-112. [CrossRef]

38. Lai, S.L.; Lu, W.-L. Impact analysis of September 11 on air travel demand in the USA. J. Air Transp. Manag. 2005, 11, 455-458. [CrossRef]

39. Lirn, T.-C.; Sheu, J.-B. The impacts of an air-crash on students' transportation choice behaviour: An empirical study undertaken in Taiwan. Transp. Res. Part F Traffic Psychol. Behav. 2009, 12, 404-416. [CrossRef]

40. Hong, S.H. The Criteria for Selecting Appropriate Fit Indices in Structural Equation Modeling and Their Rationales. Korean J. Clin. Psychol. 2000, 19, 161-177.

41. Bentler, P.M. Comparative fit indexes in structural models. Psychol. Bull. 1990, 107, 238-246. [CrossRef]

42. Bentler, P.M.; Bonett, D.G. Significance tests and goodness of fit in the analysis of covariance structures. Psychol. Bull. 1980, 88, 588-606. [CrossRef]

43. Tucker, L.R.; Lewis, C. A reliability coefficient for maximum likelihood factor analysis. Psychometrika 1973, 38, 1-10. [CrossRef]

44. Browne, M.W.; Cudeck, R. Alternative Ways of Assessing Model Fit. Sociol. Methods Res. 1992, 21, $230-258$. [CrossRef]

45. Satorra, A.; Bentler, P.M. Scaling corrections for chi-square statistics in covariance structure analysis. In $A S A$ 1988 Proceedings of the Business and Eeonomic Statistics; American Statistical Association: Alaxandria, VA, USA, 1988; pp. 308-313.

46. Lee, H.S.; Lim, J.H. Structural Equation Model Analysis and AMOS 7.0, 1st ed.; Bubmunsa: Seoul, Korea, 2008.

47. Kim, S.E. Canonical Form. Thesis at a Time; Hanbit Academy: Seoul, Korea, 2018.

48. Becker's Hospital Review. 7 Key Uncertainties Surrounding the COVID-19 Vaccine Race. 2020. Available online: https://www.beckershospitalreview.com/pharmacy/7-key-uncertainties-surrounding-the-covid-19vaccine-race.html (accessed on 9 October 2020).

49. Smithsonian MAGAZINE. Five Things to Know About Travel Bubbles. 2020. Available online: https://www.smithsonianmag.com/travel/five-things-know-about-travel-bubbles-180974983/ (accessed on 29 September 2020).

Publisher's Note: MDPI stays neutral with regard to jurisdictional claims in published maps and institutional affiliations.

(C) 2020 by the authors. Licensee MDPI, Basel, Switzerland. This article is an open access article distributed under the terms and conditions of the Creative Commons Attribution (CC BY) license (http://creativecommons.org/licenses/by/4.0/). 